\title{
Effect of perphenazine on electrogram of rat isolated heart
}

\author{
Kateřina Fialová ${ }^{1}$, Jiří Blahák ${ }^{1}$, Marek Motola ${ }^{1}$, Jří Jarkovský ${ }^{2}$ Jan Mužík², \\ Marie Nováková ${ }^{1}$ \\ ${ }^{1}$ Department of Physiology, Faculty of Medicine, Masaryk University, Brno, Czech Republic \\ ${ }^{2}$ Institute for Biostatistics and Analyses of Faculty of Medicine, Masaryk University, Brno, Czech Republic
}

Received January 27, 2010

Accepted September 21, 2010

\begin{abstract}
The aim of this study was to clarify whether administration of antipsychotic perphenazine contributes to the electrophysiological changes of the isolated heart. Fourteen adult male Wistar rats were divided into two groups. Langendorff hearts were perfused with Krebs-Henseleit solution at constant pressure $(85 \mathrm{mmHg})$ and $37{ }^{\circ} \mathrm{C}\left(\mathrm{CaCl}_{2}, 1.2 \mathrm{mM}\right)$. The electrogram was recorded by touch-free method. The hearts of the first group were exposed to $3.10^{-5} \mathrm{M}$ perphenazine, the hearts of the second group to $3.10^{-8} \mathrm{M}$ perphenazine. The incidence of arrhythmias and the heart rate and QT interval changes were studied on electrogram during 30 min periods of control, the first perphenazine administration, washout, and the second drug administration.

Perphenazine administration significantly prolonged QT $(p<0.001)$ and QTc $(p<0.05)$ in group 1. In group 2, QT and QTc prolongation was less pronounced $(p<0.05)$. A number of arrhythmias appeared, from single premature ventricular complexes to more severe ones in both groups. The heart rate changes were non-significant.

We conclude that although phenothiazines are still medicaments of choice in certain psychoses, their cardiovascular side effects should be always taken in consideration.
\end{abstract}

Phenothiazines, Langendorff heart, QT-interval, arrhythmia

Cardiovascular system disorders are among the most common causes of morbidity and mortality in developed countries. Many of them are caused by side effects of noncardiovascular drugs whose nature and mode of action vary greatly. A typical example is psychotropic drugs, substances with reported high incidence of cardiovascular side effects, often expressed as various electrophysiological changes. Their representative perphenazine has been used as a psychotropic drug for several decades in therapy of certain psychiatric disorders. It has been reported to induce asymptomatic ECG changes, tachyarrhythmias, self-terminating arrhythmias, or even ventricular fibrillation resulting in the cardiac arrest, especially when overdosed. There are no reports that perphenazine affects electrophysiological properties of the cardiac tissue at therapeutic doses, but, certain ECG changes were observed during its administration in the presence of other potentially arrhythmogenic factors (Magorien et al. 1979).

In isolated cardiomyocytes, the effects of perphenazine is functionally related to a variety of ion membrane currents. It reversibly blocks fast sodium current $I_{\mathrm{Na}}$ and transient outward potassium current $I_{t o}$. Sensitivity of $I_{N a}$ and $I_{t o}$ to perphenazine lies in the micromolar range, whereas the therapeutic plasma concentrations are in the nanomolar range (Bébarová et al. 2009). In isolated rat hearts, perphenazine at concentrations highly above the clinically relevant range caused numerous ECG changes (Langslet 1970).

Perphenazine-triggered cardiovascular side effects may be of various severities. Prolonged QT interval is supposed to be a marker for the drug arrhythmogenic capacity. Therefore, L-QT is of major concern; however, there is growing evidence that the link between QT prolongation and the risk of clinical events is poorly understood (Roden 2004).

The aim of the present study was to clarify whether administration of perphenazine contributes to the electrophysiological changes also at nanomolar concentrations.

Address for correspondence:

MUDr. Kateřina Fialová

Department of Physiology

Faculty of Medicine, Masaryk University

Kamenice 5, 62500 Brno, Czech Republic
Phone: +420549496452

Fax: +420549493266

E-mail: katy.fialova@email.cz

http://www.vfu.cz/acta-vet/actavet.htm 


\section{Materials and Methods}

Experimental groups

Experiments were performed on 14 adult male Wistar rats (average b. m. $311 \pm 33 \mathrm{~g}$ ) divided randomly into two groups. The first group was exposed to the dose $3 \cdot 10^{-5} \mathrm{M}$ of perphenazine similarly as by Langslet $(1969,1970)$. The second group was exposed to the dose $3.10^{-8} \mathrm{M}$ of perphenazine (plasma concentrations in treated patients; Omerov et al. 1989). The drug was distributed via the coronary system into the isolated heart.

Perphenazine (Sigma-Aldrich, Czech Republic) was dissolved in $96 \%$ ethanol to $10^{-3} \mathrm{M}$ stock solution. The final tested concentrations were obtained by subsequent dilution in saline solution. The final dose of ethanol was $5 \mathrm{~m} \mathrm{M}$ which was proved not to affect ion currents on the membrane of cardiomyocyte (Bébarová et al. 2010).

All animal experiments were carried out with respect to the recommendations of the European Community Guide for the Care and Use of Laboratory Animals and followed the guidelines for animal treatment approved by local authorities.

Isolated heart preparation

Animals were deeply anaesthetized with ether and their chest was opened. The heart was quickly excised and placed in cold bath containing Krebs-Henseleit $(\mathrm{K}-\mathrm{H})$ solution. The aorta was immediately cannulated, the heart was fixed to Langendorff set-up modified for pharmacological studies (Nováková et al. 2000) and perfused at constant pressure $\left(85 \mathrm{mmHg}\right.$ ) and $37{ }^{\circ} \mathrm{C}$ with $\mathrm{K}-\mathrm{H}$ solution, (in $\mathrm{mM}: 118 \mathrm{NaCl}, 4.7 \mathrm{KCl}, 25.0 \mathrm{NaHCO}_{3}, 7$ glucose, $1.2 \mathrm{KH}_{2} \mathrm{PO}_{4}, 1.2$ $\mathrm{MgSO}_{4}$ and $\left.1.25 \mathrm{CaCl}_{2}\right)$ continuously aerated $\left(95 \% \mathrm{O}_{2}, 5 \% \mathrm{CO}_{2}\right)$ The heart was placed in a thermostatically-controlled bath filled with K-H solution. The coronary effluent was continuously drained from the bath by overflow.

The experiment consisted of four 30 min periods: control, the first perphenazine administration, washout, and the second perphenazine application.

Electrograms were continually recorded from three orthogonal bipolar leads (X, Y, and Z) by the touch-free method (Nováková et al. 2000).

Data analysis

The recorded signals were stored and subsequently analysed. RR and QT intervals were measured and the incidence of arrhythmias was counted. RR intervals were averaged at the end of the control period (steady state heart rate) and the normalized heart rate (HR) was calculated. In the same way, QT intervals were evaluated and subsequently corrected to particular HR and expressed as rate-corrected QT (QT, Kawataki's formula). The severity of arrhythmias was assessed according to Lambeth Conventions (Walker et al. 1988). Premature ventricular complexes (PVCs) were counted as well as the number of episodes of ventricular tachycardia (VT) and ventricular fibrillation (VF). Each heart was given a s.-c. Lambeth score - from 0 to 5 (0 - no arrhythmia, 1 - single PVCs, 2 - salvos, 3 - VT, 4 - reversible VF, 5 - sustained VF).

The mean coronary flow was estimated every 5 min during the experiment.

Statistical analysis of the HR and QT intervals

Standard descriptive statistics both parametric and non-parametric were used for the description of each phase (mean, median, range). The differences between consecutive phases of the experiment were analysed by means of paired $t$-test. The differences between individual phases of each experiment and its control period were analysed by means of one sample $t$-test. Paired $t$-test was used for comparisons between the effects of groups 1 and 2 and to determine the significance of HR changes, QT interval prolongation and coronary flow evoked by perphenazine against the initial values for each drug dose. The time distribution of PVCs was analysed by Mann-Whitney U test.

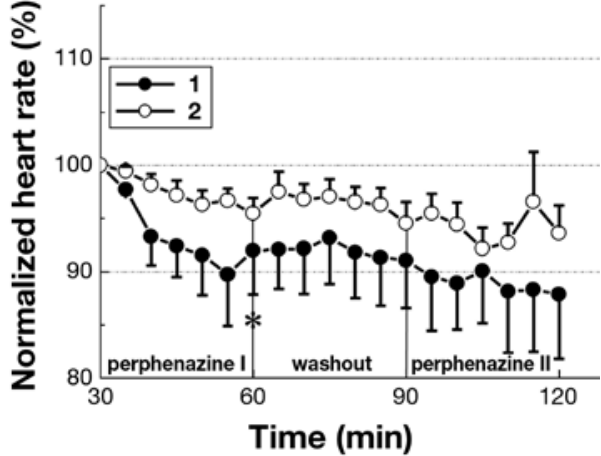

Fig. 1. Changes of normalized HR of rat isolated hearts in groups 1 and $2(* p<0.05)$.

\section{Results}

\section{Heart rate}

Normalized values of HR in both concentrations showed decreasing tendency. HR in group $1\left(10^{-6} \mathrm{M}\right)$ (Fig. 1) significantly declined during the first perphenazine period to $92 \%$ ( $p<0.05$, compared to control values), in the subsequent drug application, slightly decreased to $88 \%$. In group 2 similar changes were found, however nonsignificant. Normalized HR decreased to $94 \%$ at the end of the experiment.

\section{QT interval}

In group 1, significant $(p<0.001)$ prolongation of QT interval (by 20\%) was 


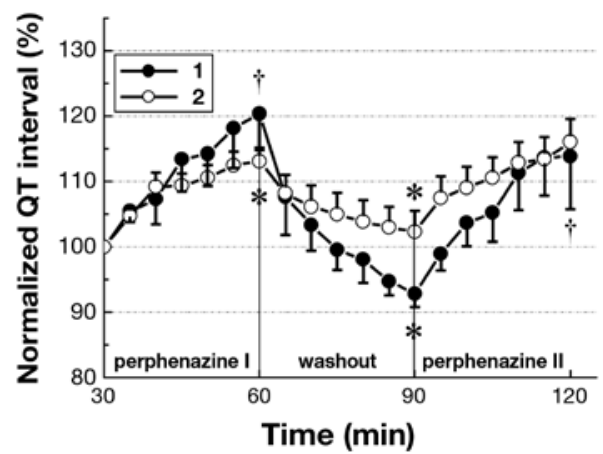

Fig. 2. Changes of normalized QT interval of rat isolated hearts in groups 1 and 2 $(* p<0.05, \uparrow p<0.001)$.

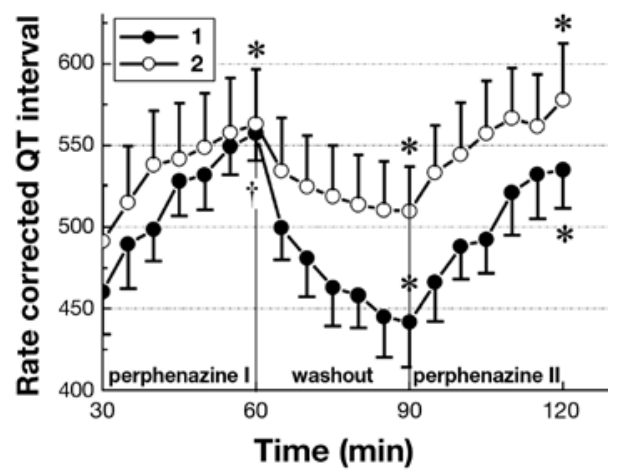

Fig. 3. Changes of QT interval of rat isolated hearts in group 1 and $2(* p<0.05, \dagger p<0.001)$. in group 2 was 291. During the second perphenazine administration, the highest incidence of PVCs, present as single ones or as part of 15 episodes of VT, was observed.

The comparison of the Lambeth score in both groups revealed that 3 hearts from group 1 and one from group 2 reached the score 0 (i.e. no arrhythmias). Score 1 was found in 2 hearts in group 1 and in 5 hearts in group 2. Score 3 (VT) was found in 2 hearts from group 1 and one from group 2 .

\section{Coronary flow}

Mean coronary flow served only as a subsidiary indicator. It did not change significantly after the perphenazine administration in either experimental group.

\section{Discussion}

The widespread overuse of drugs represents a certain risk due to the adverse side effects, drug cumulation and interactions. A frequent target of these side effects is the electrical stability of the heart.

In agreement with data of Langslet $(1969,1970)$ we proved that higher concentration of perphenazine leads to significant prolongation of QT interval. In the present study, the direct changes of QT interval following exposure to nanomolar concentrations 
Group 1
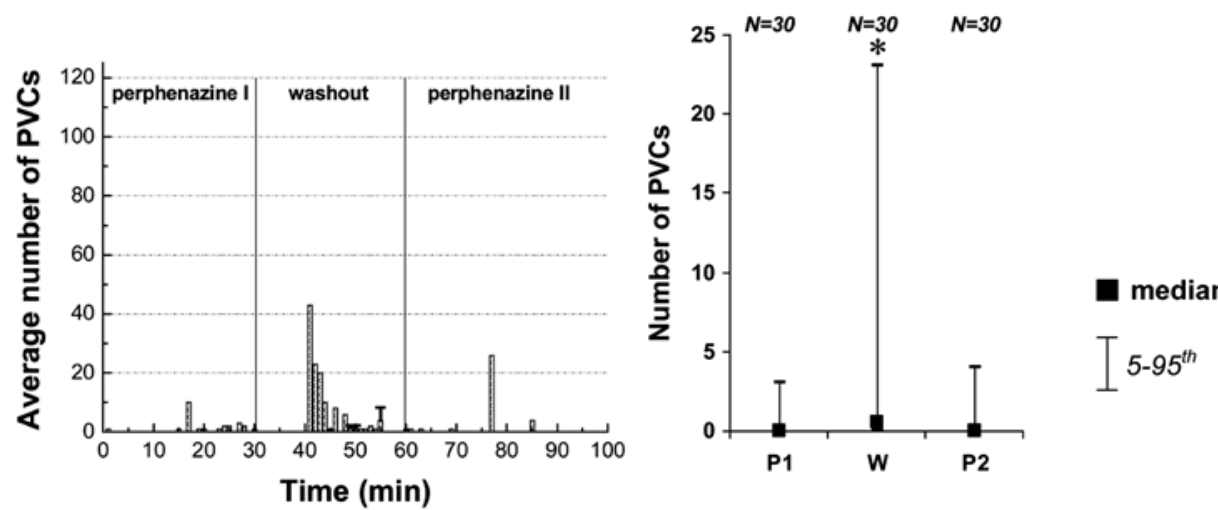

Group 2
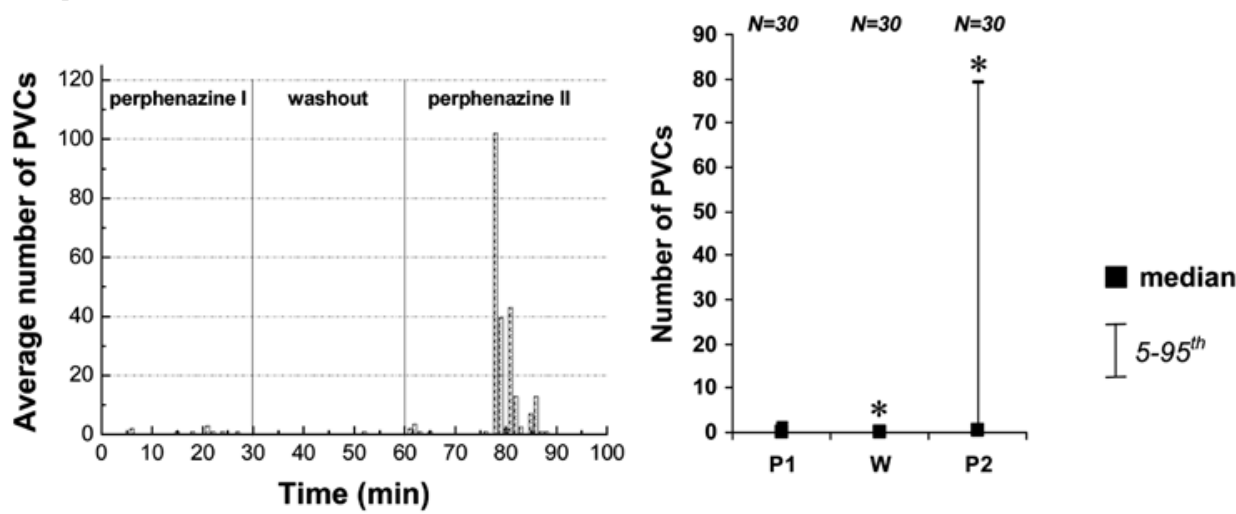

Fig. 4. Incidence of PVCs in rat isolated hearts in response to administration of perphenazine. Graphs on the right in each panel illustrate the median and $5^{\text {th }}-95^{\text {th }}$ percentile range of time distribution of PVCs and MannWhitney $\mathrm{U}$ test. (PVCs - premature ventricular complexes, $\mathrm{N}-$ number of tested samples (minutes), ${ }^{*} p<0.05$, $\dagger p<0.001)$.

of perphenazine were similar to those characterized by Langslet at micromolar concentration.

Moreover, insignificant decrease of HR at both concentrations was observed. The HR decay after exposure to the higher concentration was more pronounced. This finding is also in agreement with Langslet's results concerning a dose dependent decrease in cardiac impulse generation and conduction velocity induced by different phenothiazines among which perphenazine appeared to be one of the most efficient (Langslet 1970).

Thus, the most important finding of this study is that perphenazine significantly prolongs the QT interval and triggers arrhythmias in considerable numbers both at the high concentration and at the therapeutical concentration. This proarrhythmogenic effect is observed even after repeated exposure to perphenazine.

Prolonged QT interval may degenerate into malignant ventricular arrhythmias such as torsade de pointes (TdP), VF or cardiac arrest. Case-control studies and epidemiological data show increased incidence of sudden cardiac death in psychiatric patients taking antipsychotics (Hennessy et al. 2002). Other studies have revealed the potential of several phenothiazines to induce acquired L-QT syndrome, with prolonged $\mathrm{QT}_{\mathrm{c}}$ intervals and a 
high risk for both TdP and sudden cardiac death (Reilly et al. 2000). Nevertheless, the therapeutic potential of perphenazine is considered high and its use for the treatment of specific clinical situations is justified.

With respect to the abovementioned facts, we evaluated the incidence of arrhythmias in our model. The most interesting finding is the difference in total number and time distribution of arrhythmias during the experiment, namely, the maximum occurrence of PVCs during the second perphenazine application in the low concentration group.

A number of antipsychotics including perphenazine were identified as substances that affect sigma receptors in various tissues. They are a type of non-opioid binding sites and were reported in various tissues ( $\mathrm{Su}$ and Junien 1994), including the heart muscle (Novakova et al. 1995). Perphenazine belongs to prototypic sigma receptor ligands.

Our previous studies have been mostly performed using another sigma receptor ligand haloperidol at clinically relevant nanomolar concentrations. Arrhythmias of various severities following acute exposure to haloperidol appeared and vanished after prolonged exposure to haloperidol. It may be explained in terms of desensitization or down-regulation of sigma receptors (Fialova et al. 2009). However, our present data on incidence of arrhythmias during repeated administration of perphenazine in isolated rat heart cannot be simply explained in this way. Different total numbers of arrhythmias and also dissimilar time distribution of PVCs at the two tested concentrations indicate that this compound may act through different routes. Nevertheless, this finding deserves further examination.

\section{Účinky perfenazinu studované na modelu izolovaného srdce potkana}

Cílem práce bylo posoudit možné změny elektrofyziologických vlastností srdce po akutní aplikaci perfenazinu v nanomolárních a mikromolárních koncentracích. Byl hodnocen výskyt arytmií, změny srdeční frekvence a délky QT intervalu na modelu izolovaného srdce potkana. Do experimentu bylo zařazeno 14 samců laboratorního potkana Wistar, rozdělených na skupinu $1\left(3.10^{-5} \mathrm{M}\right.$ perfenazin) a $2\left(3.10^{-8} \mathrm{M}\right.$ perfenazin). Izolovaná srdce byla perfundována podle Langendorffa Krebs-Henseleitovým roztokem $\left(\mathrm{CaCl}_{2}, 1.2 \mathrm{mM}\right)$ za konstantního tlaku $(85 \mathrm{mmHg})$ a teploty $37^{\circ} \mathrm{C}$. Experiment byl rozdělen na čtyři úseky (30 min): kontrola, první aplikace perfenazinu, výplach, druhá aplikace perfenazinu. V průběhu celého experimentu byl bezdotykovou metodou registrován elektrogram.

Po aplikaci perfenazinu došlo ve skupině 1 k signifikantnímu prodloužení QT $(p<0.001)$ a QTc $(p<0.05)$. Ve skupině 2 došlo k prodloužení QT a QTc na hladině významnosti $p<0.05$. U obou skupin zvírat se po akutní expozici perfenazinu objevily arytmie různé závažnosti. Změny srdeční frekvence byly nesignifikantní.

Fenothiaziny jsou stále lékem volby u některých akutních i chronických psychóz. Jejich vedlejší účinky na kardiovaskulární systém by však měly být vždy brány v úvahu.

\section{Acknowledgements}

This work was supported by the grant projects GACR 102/07/1473 and MSM0021622402.

The authors thank Prof. Pavel Braveny for fruitful discussion over the manuscript and Ms. Branislava Vyoralova for excellent technical help during the experiments.

\section{References}

Bébarová M, Matejovič P, Pásek M, Jansová D, Šimurdová M, Nováková M, Šimurda J 2009: Effect of antypsychotic drug perphenazine on fast sodium current and transient outward potassium current in rat ventricular myocytes. Naunyn Schmiedebergs Arch Pharmacol 380:125-133

Bébarová M, Matejovič P, Pásek M, Ohlídalová D, Jansová D, Šimurdová M, Šimurda J 2010: Effect of ethanol on action potential and ionic membrane currents in rat ventricular myocytes. Acta Physiolog doi: 10.1111/j.17481716.2010.02162.x

Fialova K, Krizanova O, Jarkovsky J, Novakova M 2009: Apparent desensitization of the effects of sigma receptor ligand haloperidol in rat and guinea pig isolated hearts after chronic treatment. Can J Physiol Pharmacol 87: 1019-1027 
Hennessy S, Bilker WB, Knauss JS, Margolis DJ, Kimmel SE, Reynolds RF, Glasser DB, Morrison MF, Strom BL 2002: Cardiac arrest and ventricular arrhythmia in patients taking antipsychotic drugs: cohort study using administrative data. BMJ 325: 1070-1074

Langslet A 1969: Changes in coronary flow and ECG in the isolated perfused rat heart induced by phenothiazine drugs. Acta Pharmacol Toxicol (Copenh) 27: 183-192

Langslet A 1970: ECG-Changes Induced by Phenothiazine Drugs in the Anaesthetized Rat. Acta Pharmacol Toxicol (Copenh) 28: 258-264

Magorien RD, Jewell GM, Schaal SF, Leier CV 1979: Electrophysiologic studies of perphenazine and protriptyline in a patient with psychotropic drug-induced ventricular fibrillation. Am J Med 67: 353-357

Novakova M, Ela C, Barg J, Vogel Z, Hasin Y, Eilam Y 1995: Inotropic action of sigma receptor ligands in isolated cardiac myocytes from adult rats. Eur J Pharmacol 286: 19-30

Nováková M, Moudr J, Bravený P 2000. A modified perfusion system for pharmacological studies in isolated hearts. Analysis of Biomedical Signals and Images 16: 162-164

Omerov M, Wistedt B, Bolving-Hansen L, Larsen NE 1989: The relationship between perphenazine plasma levels and clinical response in acute schizophrenia. Prog Neruropsychopharmacol Biol Pychiatry 13: 159-166

Reilly JG, Ayis SA, Ferrier IN, Jones SJ, Thomas SHL 2000: QTc-interval abnormalities and psychotropic drug therapy in psychiatric patients. Lancet 355: 1048-1052

Roden DM 2004: Drug-induced prolongation of the QT interval. N Engl J Med 350: 1013-1022

Su TP, Junien JL 1994: Sigma receptors in the central nervous system and the periphery. In: Itzhak Y, Bowen WD (Ed.): Sigma Receptors. Academic Press Limited, London, pp. 21-44

Walker MJA, Curtis MJ, Hearse DJ, Campbell RWF, Janse MJ, Yellon DM, Cobbe SM, Coker SJ, Harness JB, Harron DW, Higgins AJ, Julian DG, Lab MJ, Manning AS, Northover BJ, Parratt JR, Riemersma RA, Riva E, Russell DC, Sheridan DJ, Winslow E, Woodward B 1988: The Lambeth Conventions: guidelines for the study of arrhythmias in ischaemia, infarction, and reperfusion. Cardiovascular Res 22: 447-455 